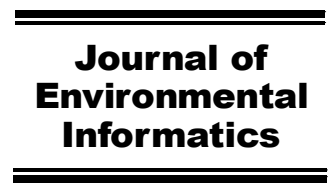

Www.iseis.org/jei

\title{
Detection of the Sensitive Inflowing River Indicators Related to Non-Point Source Organic Pollution: A Case Study of Taihu Lake
}

\author{
C. $\operatorname{Lin}^{1 *}$, R. H. Ma ${ }^{1}$, Z. P. Wu' ${ }^{2}$ J. F. Xiong ${ }^{1,3}$, and M. Min ${ }^{1}$ \\ ${ }^{1}$ Key Laboratory of Watershed Geographic Sciences, Institute of Geography and Limnology, Chinese Academy of Sciences, \\ Nanjing 210008, China \\ ${ }^{2}$ School of Geographic and Oceanographic Sciences, Nanjing University, Nanjing 210046, China \\ ${ }^{3}$ School of Geographic and Remote Sensing Sciences, Nanjing University of Information Science \& Technology, Nanjing 210044, China
}

Received 20 June 2015; revised 11 April 2016; accepted 29 April 2016; published online 24 October 2016

\begin{abstract}
Organic matter transport from watershed soil into an aquatic ecosystem plays a key role in the fate of contaminants and lake eutrophication. Special emphasis is needed to understand whether sensitive river indicators can reflect watershed non-point source organic carbon (OC) pollution, in which the accurate assessment of non-point source (NPS) pollution is crucial. This study selected a sub-basin within the Taihu basin, China, as the study site, a typical rural-urban fringe region undergoing rapid urbanization where soil organic carbon (SOC) loss would likely take place due to the integration of agriculture NPS and impervious surface NPS. The seasonal tendency of NPS soil organic carbon (SOC) loads were evaluated by using the integration of SEDD and PLOAD models, which consider the sediment adsorption fraction loads (Sed-OC) and runoff dissolved fraction loads (Dis-OC) together. And then the sensitive water indicators for OC loads were determined by measurements of inflowing river properties and stepwise regression analysis. The results showed that active dissolved carbon fraction loads were the dominant contributors to the total organic carbon loads (Tot-OC) and that Sed-OC loads have more spatial variation. With respect to sensitive river properties, the lignin owned the greatest correlation degree with different OC fraction loads, in which the correlation coefficient between particulate lignin and Sed-OC loads reached 0.782, which is the greatest among the different indicators. In addition, the colored dissolved organic matter (CDOM) was also correlated with Dis-OC loads. However, the particulate organic carbon (POC) was not well related to OC loads. The findings of this study are useful for better understanding the nutrient migration from watershed soil into aquatic ecosystem controlled by watershed NPS pollution.
\end{abstract}

Keywords: soil organic carbon, non-point source pollution, dissolved and sediment fractions, lignin, Taihu Lake watershed

\section{Introduction}

Soil organic carbon (SOC) plays a major role with respect to many chemical and physical processes in aquaticterrestrial ecosystems (Teisserenc et al., 2010). Non-point source (NPS) pollution drive the soil organic matter (SOM) delivered from watershed into surface water through sediment and runoff (Ouyang et al., 2010). This consequently increases organic carbon (OC) loads in aquatic ecosystems, promoting the growth of blue-green cyanobacteria and organic pollutants and leading to some environmental problems, such as lake eutrophication (Neff et al., 2003; Ning et al., 2006; Yang et al., 2012). Therefore, understanding the features of NPS OC pollution in aquatic-terrestrial ecosystems is helpful for the research of earth biogeochemical cycling, and also of great significance for the protection of watershed environments.

${ }^{*}$ Corresponding author. Tel.: +(86) 25-86882169; fax: +(86) 25-83592686.

E-mail address: clin@niglas.ac.cn (C. Lin).

ISSN: 1726-2135 print/1684-8799 online

(c) 2016 ISEIS All rights reserved. doi: 10.3808/jei.201600343
The SOM loss in watersheds is largely sourced from NPS pollution. Actually, the NPS pollution could be categorized as two types: agriculture non-point source (ANPS) pollution and urban non-point source pollution. Most models always focused on ANPS and predominantly consider particle-absorbed organic carbon loads, which involve two processes: soil erosion and sediment delivery (Nearing et al., 1989; Blair and Aller, 2012). Compared with physical models, the classical empirical models are more suitable and widely used in watershed scale monitoring due to the advantages of condensed structures, accessible parameters and simple and efficient operation (McDowell et al., 2002; Be-chmann et al., 2009; Laurent and Ruelland, 2011; He et al., 2012; Chen et al., 2013). In particular, the most recognized exponential model is the Revised Universal Soil Loss Equation (RUSLE), which has been widely applied to evaluate soil erosion modulus by integrating several factors, including climate, land use, soil and topography ( $\mathrm{Li}$ et al., 2009; Ouyang et al., 2010). Based on the fundamental form of RUSLE, the sediment delivery distributed (SEDD) model has been recently improved by researchers. One of the improvements is to take the sediment delivery factor into account, and thereby, the loss of the 
absorbed nutrients in soil sediment can be quantitatively and more precisely monitored (Yang et al., 2012). In addition to ANPS, more attention has been paid to the watershed organic matter loss in surface runoff in recent decades, especially in some rapidly urbanized regions. In these regions, the surface runoff becomes a main carrier for NPS SOC loads, and the SOC is prone to loss in dissolved and active fraction because the natural soil surface has been replaced with impermeable surfaces. USEPA (2001) developed the PLOAD model to calculate annual NPS pollution loads in runoff, which has been widely applied due to the advantages of a lower data requirement and vivid results visualization of storm water permission (Shi et al., 2012). Above all, it is worth mentioning that an effective method for the calculation of NPS SOC loads needs to consider both particulate organic matter loads from sediment delivery and dissolved organic matter loads from surface runoff (Cui et al., 2003).

Additionally, the impact of watershed NPS pollution on the quality of aquatic systems has been quantified by the studies based on the results of NPS loads. The NPS pollution loads were used to relate numerous water indicators for inflowing rivers and lakes, including water temperature, turbidity, $\mathrm{pH}$ and water chemistry indicators (Stambuk-Gilijanovic, 2003; Liou et al., 2004). High levels of NPS loads were found to be associated with poor water quality (Santhi et al., 2001; Wu et al., 2013). These results were helpful for understanding the relationship between NPS pollution and water quality. However, existing studies are mainly focused on the linkage between lake indicators and NPS phosphorus and nitrogen loads, because TP and TN are the most important inducements to lake eutrophiccation (Hood et al., 2003; Teisserenc et al., 2010), the relationship between NPS OC loads and aquatic indicators was rarely analysed. For this case, the critical indicators within the river or lake that were sensitive to differrent NPS OC loads have not been quantitatively determined. This investigation could benefit from an understanding of the fate of OC delivered from watershed soil into aquatic ecosystems.

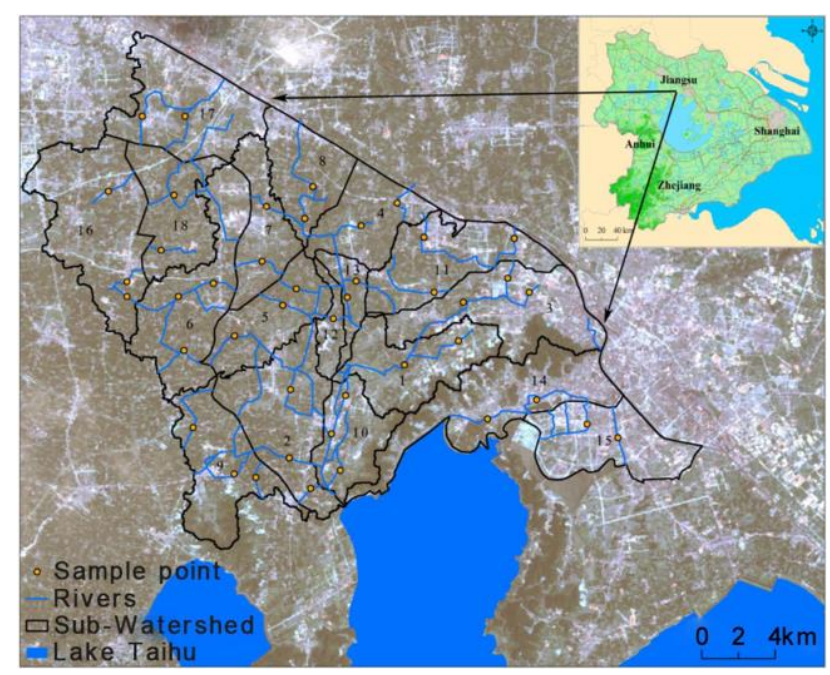

Figure 1. Location of study site and sampling points.
With the rapid urbanization and significant anthropogenic influence in the recent 30 years, the watershed of Meiliang Bay within Taihu Lake, China, has suffered from severe NPS pollution, and the lake water has also experienced the most severe eutrophication intensity (Duan et al., 2015). The objectives of the present study are to: i) assess the spatial and temporal features of watershed NPS SOC loads using the integration of SEDD and PLOAD models, which consider the sediment adsorption fraction and runoff dissolved fraction together. ii) Determine the critical indicator that is sensitive to the NPS SOC loads from numerous related inflowing river indicators, including DOC, POC, CDOM and lignin etc. The findings from this study could be used to simplify the representation of watershed NPS loads and provide a practical foundation for the environmental protection of watersheds.

\section{Material and Methods}

\subsection{Study Site}

The watershed region of Meiliang Bay is located in an upstream watershed area of the Taihu Watershed, China, and located on the eastern coast of China and south of the Yangtze River Delta. This selected region covered a total area of 486 $\mathrm{km}^{2}$ and is located in a peri-urban area between Wuxi and Changzhou cities, which are famous for their natural conditions and advantageous economic development with the most extensive agriculture, urbanization and industry in Jiangsu province. The average annual precipitation in the study area is $1035 \mathrm{~mm}$, and the main rainfall season is from May to October. The annual mean runoff depth is $688 \mathrm{~mm}$, and the annual average temperature is $15.6^{\circ} \mathrm{C}$. The main soil type in this area is bleached paddy soil, which covers more than $85 \%$ of the study site. The dominated fertilizer types are nitrogen fertilizer and phosphate fertilizer. The background content of soil organic matter (SOM), total phosphorus (TP), total nitrogen (TN) content is $1.97 \mathrm{~g} \mathrm{~kg}^{-1}, 0.07 \mathrm{~g} \mathrm{~kg}^{-1}$ and $0.12 \mathrm{~g} \mathrm{~kg}^{-1}$ respectively. Sand proportion accounts for $13.14 \%$ and $\mathrm{pH}$ is 5.97 (Gong et al., 2003). The sub-watershed is densely covered by a river network consisting of three trunk streams with their tributaries, including Wujin Port, and the Yangxi and Liangxi Rivers, which flow into Meiliang Bay in Taihu Lake. Eighteen sub-basins were generated by ArcGIS based on the three inflow Rivers (Figure 1). Moreover, the study area is undergoing dramatic land use adjustments and rapid urbanization in the last 30 years, a large amount of arable land and forestland has been replaced by construction ( $\mathrm{Li}$ et al., 2007). Currently, construction land and arable land cover most of the study area, in which more than $30 \%$ of the area is impervious surface and $55 \%$ is arable land. The watershed region suffers from severe NPS pollution due to extensive agricultural activities and urbanization, the eutrophication in Meiliang Bay is the most serious within the Taihu Lake, largely as a result of the constant delivery of soil nutrients into inflowing rivers by NPS pollution, which have contributed to lake eutrophication. 


\subsection{Spatial and Temporal Evaluation of NPS SOC Loads}

The NPS SOC loads in 2014 were assessed in this study, and the statuses of the loads were considered in four seasons due to the significant variation in NPS SOC loads among different seasons. Both sediment-adsorbed organic carbon fraction loads (Sed-OC) and active dissolved carbon fraction loads (Dis-OC) were calculated, and the total carbon fraction loads (Tot-OC) could be derived from these two components.

\subsubsection{Assessment of Sed-OC loads component}

The spatial features of Sed-OC loads within different seasons were estimated with equation (1). The model involved two important factors, including soil erosion and sediment delivery (Yang et al., 2012), in which the soil erosion modulus was calculated by the Revised Universal Soil Loss Equation (RUSLE) (Cui et al., 2003). The model was calculated in ArcGIS 10.0 using $30 \mathrm{~m} \times 30 \mathrm{~m}$ spatial grids:

$L_{s e d-o c}=A_{i} \times O C_{\text {sed }} \times S D R_{i}$

where $L_{s e d-o c}$ represented Sed-OC loads per unit area $(\mathrm{kg}$ $\left.\mathrm{km}^{-2} \mathrm{yr}^{-1}\right) ; A_{i}$ is the soil erosion modulus $\left(\mathrm{kg} \mathrm{km}^{-2} \mathrm{yr}^{-1}\right), O C_{\text {sed }}$ expresses the sediment SOC concentration status $\left(\mathrm{g} \mathrm{kg}^{-1}\right)$, which was achieved by field sampling in different land use types of each sub-basin and laboratory measurements. $S D R_{i}$ is the sediment delivery ratio $(\%)$ for each grid. Specially, the $S D R_{i}$ was calculated by the equation (2), which was referenced by Ferro (1997):

$$
S D R_{i}=\exp \left(-\beta t_{i}\right)
$$

where $t_{i}$ is the travel time (h) from grid $i$ to the nearest river channel along the flow path, and $\beta$ is a coefficient that lumps together the effects of roughness and runoff along the flow path (Ferro, 1997). The sensitivity of $S D R$ to $\beta$ is watershedspecific, and the value of 0.304 is suitable for the watershed because this value produces the smallest mean relative square error between the modeled and measured sediment yield (Ferro, 1997). Travel time can be calculated based on equation (3) (Jain and Kothyari, 2000), in which $l_{j}$ is the flow length and $v_{j}$ is a velocity factor derived from Smith and Maidment (1995):

$$
t_{i}=\sum_{j=1}^{N P}\left(\frac{l_{j}}{v_{j}}\right)
$$

Moreover, the core component of the Sed-OC quantization method was the soil erosion modulus, which was calculated by RUSLE given by equation (2), which is calculated based on the following model:

$$
A_{i}=R_{i} \times K_{i} \times L S_{i} \times C_{i} \times P_{i}
$$

where $R_{i}$ is the rainfall-runoff erosivity factor (MJ $\mathrm{mm}$ (ha $\mathrm{h}$ $\left.\mathrm{yr})^{-1}\right) ; K_{i}$ is the soil erodibility factor $\left(\mathrm{Mg} \mathrm{h} \mathrm{MJ}^{-1} \mathrm{~mm}^{-1}\right) ; L S_{i}$ is the slope length and steepness factor, in which the $L$ is slope factor and $S$ is the steepness factor; $C_{i}$ is the cover management factor; and $P_{i}$ is the conservation support practice factor, which is based on land uses (Dabral et al., 2008). The algorithm of the $R$ factor used in this study is given by the following (Wischmeier and Smith, 1987):

$R_{i}=1.735 \times 10^{\left(1.5 \times \lg \left(\frac{P^{2} m}{P}\right)-0.8188\right)}$

where $P_{m}$ is the monthly average rainfall $(\mathrm{mm})$ and $P$ is the annual average rainfall $(\mathrm{mm})$. The $K_{i}$ value was assigned by the soil type spatial distribution map (1:1000000) and reference to the study of $\mathrm{Bu}$ et al (2003) which was conducted in the Taihu Basin.

The factor $L S_{i}$ reflects the effects of topography on soil erosion and is the acceleration factor of erosion power. $L S_{i}$ factors include slope length and steepness factors. Slope lengths longer than $3 \mathrm{~m}$ can be extracted in a digital elevation model (DEM). The $L$ and $S$ factors used in the study are calculated according to McCool et al., (1987) and Onyando et al. (2005), and the models are shown in Equation (6), in which $\theta$ is the slope angle in degrees, and $\lambda$ is the field slope length $(\mathrm{m})$ :

$$
\begin{gathered}
L=\left(\frac{\lambda}{22.13}\right)^{m}=\begin{array}{lc}
m=0.2 & \theta<0.5^{\circ} \\
m=0.3 & 0.5^{\circ} \leq \theta<1.5^{\circ} \\
m=0.4 & 1.5^{\circ} \leq \theta<3.0^{\circ} \\
m=0.5 & \theta \geq 3.0^{\circ}
\end{array} \\
S= \begin{cases}10.8 \sin (\theta)+0.03 & \theta<5^{\circ} \\
16.8 \sin (\theta)+0.50 & 5^{\circ}<\theta<10^{\circ} \\
21.9 \sin (\theta)+0.03 & \theta \geq 10^{\circ}\end{cases}
\end{gathered}
$$

The $P_{i}$ is determined as the ratio between the soil losses expected for a certain soil conservation practice and those usually estimated based on landuse type. In this study, the $P_{i}$ assignment referenced $\mathrm{Xu}$ et al. (2012), which was determined by a local investigation in the Taihu Basin. $C$ is defined as the cover-management factor, which express the protective effect of soil cover against the erosive action of rainfall. $\mathrm{C}$ - factor mapping by remote sensing can provide essential information for improving the spatial modeling of soil erosion (Durigon et al., 2014). In this study, the C factor is calculated by referring to the study of Durigon et al. (2014), which involves the use of a regression equation derived from a satellitederived Normalized Difference Vegetation Index (NDVI).

\subsubsection{Assessment of Dis-OC Loads Component}

The PLOAD model is a GIS-based model, which is used to calculate non-point source pollutant loads from different sub-watersheds based on land uses and annual or seasonal precipitation data (USEPA, 2001). In the present study, the 
Table 1. The Data Source for the Calculation of the NPS P Loads

\begin{tabular}{|c|c|c|}
\hline Data type & Data source & Description \\
\hline Land use (Figure 2) & $\begin{array}{l}\text { Second National } \\
\text { Land Survey of } \\
\text { China. }\end{array}$ & $\begin{array}{l}\text { The data were interpreted from a Resource Satellite ST.3 (ZY-3) image in the second national } \\
\text { land survey of China, and the data were merged into six main types for the convenience of the } \\
\text { study (forestland, arable land, orchard land, wetland, construction land and other land). The } \\
\text { modeling factors including conservation support practice factor (P), runoff coefficient (Rn), } \\
\mathrm{OC}_{\text {dis }} \text { and } \mathrm{OC}_{\text {sed }} \text { were assigned based on land uses. }\end{array}$ \\
\hline $\begin{array}{l}\text { Remote sensing } \\
\text { image }\end{array}$ & $\begin{array}{l}\text { Landsat Enhanced } \\
\text { Thematic Mapper } \\
(\text { ETM+) data }\end{array}$ & $\begin{array}{l}\text { The ETM+ data with a spatial accuracy of } 30 \mathrm{~m} \text { was acquired from USGS, and the satellites } \\
\text { transit date is Aug } 2,2013 \text {, the closest date to the actual sampling period. The NDVI data } \\
\text { were the basis of the cover-management factor assignment, which was interpreted from the } \\
\text { image. }\end{array}$ \\
\hline $\begin{array}{l}\text { Digital Elevation } \\
\text { Model (DEM) }\end{array}$ & $\begin{array}{l}\text { ASTER global } \\
\text { DEM }\end{array}$ & $\begin{array}{l}\text { The data acquired from USGS, and the spatial accuracy is } 30 \mathrm{~m} \text {. The length-slope factor (LS) } \\
\text { was calculated from the length and slope spatial data. }\end{array}$ \\
\hline Runoff amount & $\begin{array}{l}\text { Meteorological } \\
\text { monitoring stations } \\
\text { in Taihu Basin, }\end{array}$ & $\begin{array}{l}\text { Four monitoring stations were located in our study sites; the average annual rainfall amount } \\
\text { was acquired and then interpolated onto the spatial scale. The rainfall intensity (R) factor was } \\
\text { calculated from the spatial rainfall data. }\end{array}$ \\
\hline $\begin{array}{l}\text { Soil type and soil } \\
\text { properties } \\
\text { background data }\end{array}$ & $\begin{array}{l}<\text { Soil Annals of } \\
\text { Jiangsu Province }>\end{array}$ & $\begin{array}{l}\text { The data were digitized from <Soil Annals of Jiangsu Province }>\text {, the soil erodibility factor }(\mathrm{K}) \\
\text { was assigned based on the soil types and background data, including the soil mechanical } \\
\text { composition and the soil organic concentration within each soil type. }\end{array}$ \\
\hline
\end{tabular}

PLOAD model is designed for the estimation of seasonal dissolved non-point source nutrients loads:

$L_{D i s-O C}=O C_{i} \times P j_{i} \times R n_{i} \times C_{r u n}$

where $L_{D i s-O C}$ represents the dissolved non-point source nutrient loads per season $\left(\mathrm{kg} \mathrm{km}^{-2} \mathrm{yr}^{-1}\right)$ for each grid pixel; $P_{i}$ is the precipitation per season $\left(\mathrm{mm} \mathrm{yr}^{-1}\right) ; P j_{i}$ is the ratio of storm producing runoff (default $=0.9$ ); $R n_{i}$ is the runoff coefficient, which was evaluated based on each land use type, and derived with the following equation:

$R_{n}=0.05+\left(0.009 \times I_{i m p}\right)$

where $I_{i m p}$ is the imperious factor for different land uses, and the value is selected from the guidelines provided by NRCCS, TR-55 user's manual (USEPA, 2003). $C_{r u n}$ is the event mean concentration (EMC) for the land use type $\left(\mathrm{mg} \mathrm{L}^{-1}\right)$, which is determined by the runoff from a specific event by taking flow samples at regular intervals during the event and using following equation:

$E M C=\frac{\sum O C_{d i s} Q_{n}}{\sum Q_{i}}$

$O C_{d i s}$ is the OC concentration of sample $n$, and $Q_{n}$ is the flow rate. The water examples were obtained after the generation of surface runoff from each rainfall event using a PLOAD simulation. In this study, two critical rainfall events per season were selected. The measured Dis-OC concentrations in runoff were averaged and then designated as the $O C_{\text {dis }}$ value of each land use.

\subsubsection{NPS OC Load Assessment}

In this study, the total NPS OC loads for each season were determined by the dissolved and adsorbed components together. The equations were given as follows:

$$
L_{T o t-O C}=\left(\sum_{i}^{n} L_{s e d-O C}+\sum_{i}^{n} L_{d i s-O C}\right) \times A_{U}
$$

where $\operatorname{Tot}(P)$ is the introduction of NPS nutrients into the rivers $\left(\mathrm{kg} \mathrm{yr}^{-1}\right)$; and $\mathrm{AU}$ is the area of the land use type $\left(\mathrm{km}^{2}\right)$ within each sub-basin. The model was implemented in ArcGIS 10.0 based on a raster grid $(30 \mathrm{~m} \times 30 \mathrm{~m})$, and then clustered into each sub-basin.

\subsection{Selection of Sensitive Water Indicators within Inflow- ing Rivers}

The organic matter in the water and related water indicators were correlated with the watershed OC loads. The inflowing river indicators sensitive to OC pollution were then identified. The fate of SOC delivered from a watershed to inflowing rivers could be further analysed.

Several water indicators were collected and measured in the laboratory in each season. The indicators were included: (i) dissolved organic carbon (DOC) and particulate organic carbon (POC), which represented the different existing form of organic carbon substances in the water (Duan et al., 2015); (ii) CDOM, the colored fraction of DOM, which originated from the decomposition of plant matter within the aquatic environment, as well as through the transport of partially degraded organic material from the surrounding watershed environment (Yamashita and Tanoue, 2008; Zhang et al., 2009); (iii) the chemical oxygen demand (COD), an important parameter used to describe the intensity of organic contamination; and lastly, iv) the dissolved lignin (d-lig) and particulate lignin (p-lig), which were widely used as important biomarkers for terrigenous organic matter tracing but rarely related to NPS pollution in previous studies (Gordon and Goñi, 2003; Bao et al., 2014) 
Table 2. The Information of Selected Typical Rainfall Events

\begin{tabular}{llllll}
\hline No & Date & Season & Temperature & Temporal duration & Rainfall \\
\hline 1 & 18 Dec, 2013 & Winter & 5.2 & $73 \mathrm{~min}$ & $43.6 \mathrm{~mm}$ \\
2 & $2 \mathrm{Feb}, 2014$ & Winter & -0.2 & $82 \mathrm{~min}$ & $48.0 \mathrm{~mm}$ \\
3 & $7 \mathrm{Mar}, 2014$ & Spring & 13.0 & $109 \mathrm{~min}$ & $72.1 \mathrm{~mm}$ \\
4 & $8 \mathrm{May}, 2014$ & Spring & 20.0 & $92 \mathrm{~min}$ & $60.0 \mathrm{~mm}$ \\
5 & $28 \mathrm{Jul}, 2014$ & Summer & 36.2 & $114 \mathrm{~min}$ & $100.02 \mathrm{~mm}$ \\
6 & 9 Aug, 2014 & Summer & 33.2 & $156 \mathrm{~min}$ & $112.82 \mathrm{~mm}$ \\
7 & $28 \mathrm{Sep}, 2014$ & Autumn & 24.2 & $189 \mathrm{~min}$ & $132.77 \mathrm{~mm}$ \\
8 & 9 Nov, 2014 & Autumn & 20.1 & $89 \mathrm{~min}$ & $72.2 \mathrm{~mm}$ \\
\hline
\end{tabular}

\subsection{Data Collection}

The field sampling data and spatial data were gathered in this study. The spatial data consisting of land use/cover data, the soil type data, the digital evaluation data and runoff data were used to quantify the modeling factors in the estimation of OC loads (Table 1).

The field data plays an important role in model assessment and validation, and the dataset can be divided into monitoring data and sampling data, in which the monitoring data refers to the observed sediment and surface water OC discharge data measured at different monitoring sites. These data were collected after typical rainfall events throughout all four seasons (Table 2). The monitoring data were used to quantify the modeling factors, such as $O C_{\text {sed }}$ and $O C_{d i s}$. In additional, the sampling data refers to the selected water indicators derived from the inflowing rivers in all the subbasins (Figure 2). The surface water sampling was performed on the dates shown above and during the morning hours from 8:00 to $13: 30$. The samples were collected in airtight glass jars with a $250-\mathrm{ml}$ capacity, and the all the samples were transported to the laboratory for refrigeration to prepare for water properties measurements. Specifically, the samples were filtered through precombusted $\left(6 \mathrm{~h}\right.$ at $\left.450{ }^{\circ} \mathrm{C}\right) 47 \mathrm{~mm}$ Whatman $\mathrm{GF} / \mathrm{F}$ glass fiber filters $(0.7 \mathrm{um})$ at a low doc vacuum, using a Shimadzu TOC-5000A analyzer, following the protocol of Chen et al (2004) for DOC analysis (Jiang et al., 2012). The POC concentrations were measured by the combustion of sample filters in an EA3000 elemental analyzer (Biddanda and Benner, 1997). With respect to CDOM, the CDOM absorption spectra were obtained between 200 and $800 \mathrm{~nm}$ at $1-\mathrm{nm}$ intervals using a Shimadzu UV-2450 PC UV-Vis spectrophotometer with matching 5-cm quartz cells. Milli-Q water was used in the reference cell. Absorbance measurements at each wavelength $(\mathrm{k})$ were baseline corrected by subtracting the absorbance values at $700 \mathrm{~nm}$. The absorption coefficients were obtained by the following equation:

$$
a_{C O D M}(\lambda)=\frac{2.303 D(\lambda)}{r}
$$

where $a_{C O D M}(\lambda)$ represented the CDOM absorption coefficient at wavelength $\lambda, D(\lambda)$ is the corrected optical density at wavelength $\lambda$, and $r$ is the path length in $\mathrm{m}$. In the present study, the concentration of CDOM is expressed as $a_{C O D M}$ (443) (Zhang et

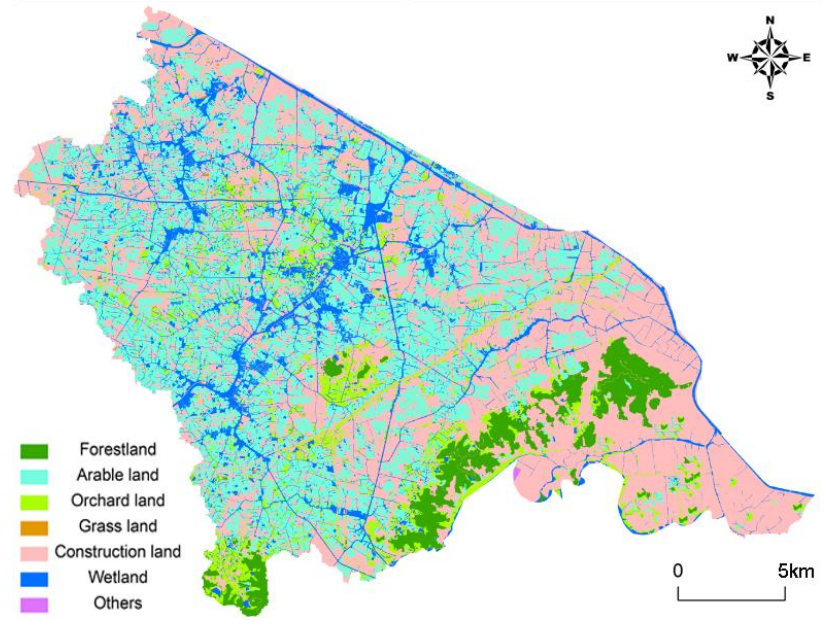

Figure 2. Land use characteristics of the study site.

al., 2009). The COD was measured by a colorimetric method with a potassium dichromate-sulfuric acid solution as the reagent (Yao et al., 2011). These indicators mentioned above were measured by the State Key Laboratory of Lake Science and Environment, Nanjing Institute of Geography and Limnology, Chinese Academy of Sciences. The dissolved and particulate lignin were measured by the analysis and determination center of Nanjing Normal University, using Agilent 1290 Infinity LC for chromatographic separation and an Agilent 6460 mass spectrometer for the lignin analysis (Casas et al., 2014).

Finally, the measured water indicators that belonged to the same sub-basin were averaged, which represented the water properties of the target sub-basin. For all of the above, the sampling data were linked with OC loads to identify the inflowing river properties that were sensitive to NPS OC pollution.

\subsection{Relationship between NPS OC Loads and Water Indi- cators on the Sub-Basin Scale}

The relationships between different NPS OC load fractions and water properties within eighteen sub-basins and four seasons were analysed for the purpose of identifying sensitive inflowing river indicators. A Pearson correlation analysis was performed using SPSS 19.0, and the correlation coefficient $(r)$ was used to assess the correlation between various water indi- 
cators and three OC load fractions. Furthermore, a stepwise regression analysis was also performed between different NPS OC load fractions and water parameters. Because the load of each OC was dependent and each water indicator was independent, the $F$ statistic was taken as the criterion of the step- wise regression, in which $F$-enter and $F$-remove were set as 0.05 and 0.1 . A $t$-test was used to identify the significance of the coefficients of the independent variables $(p \leq 0.05)$ entered in the final stepwise model (Basnyat et al., 2000; Ferguson et al., 2008).
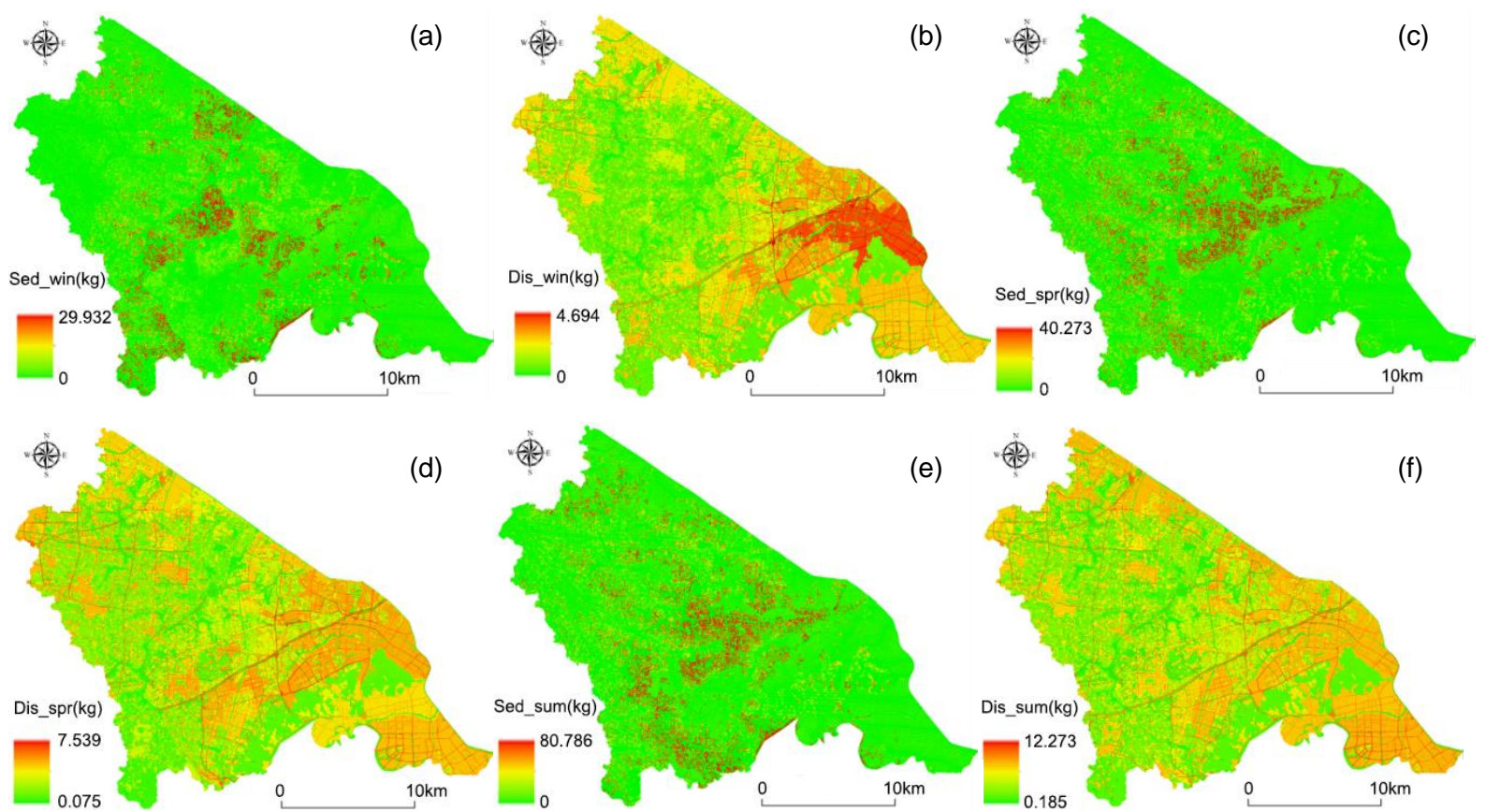

(e)

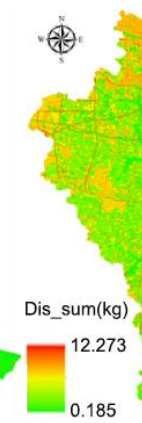

(f)
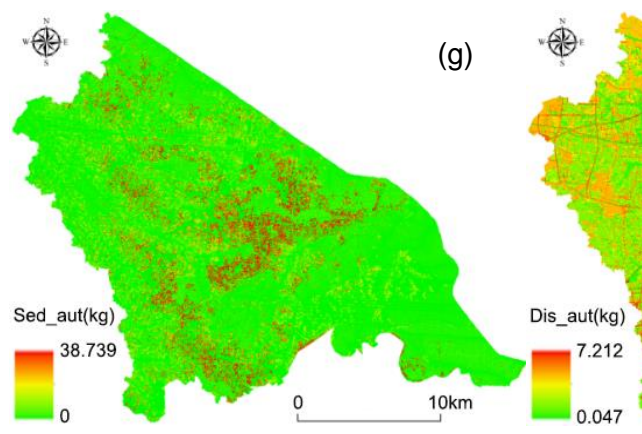

$10 \mathrm{~km}$
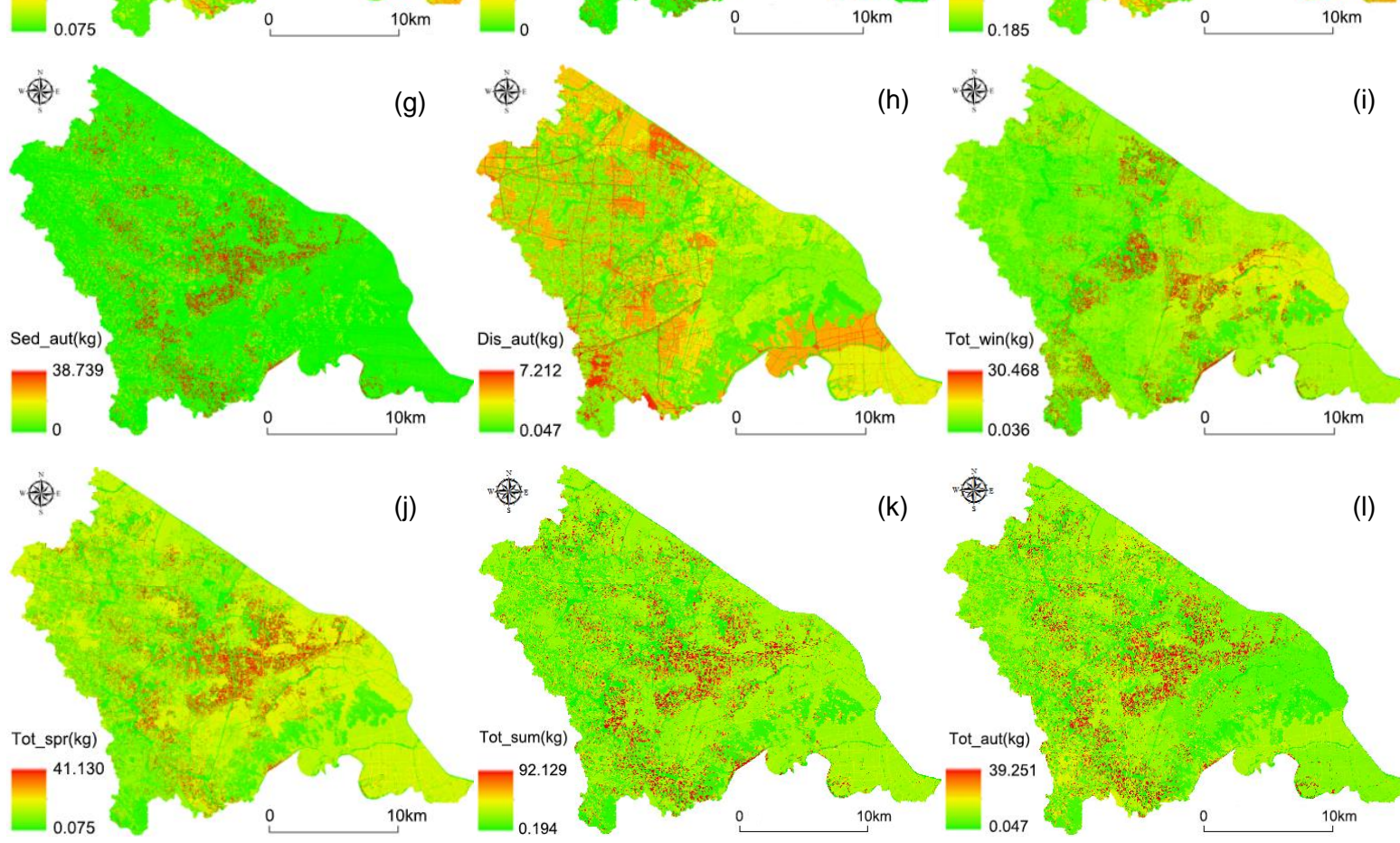

(h)

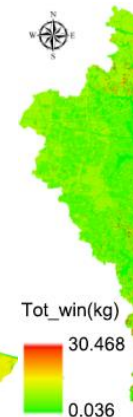

(i)

Figure 3. Spatial distributions of watershed seasonal soil organic carbon loss in 2014. Note that Sed_win and Dis_win are the Sed-OC loads and Dis-OC loads in the winter; Sed_spr and Dis_spr are the Sed-OC loads and Dis-OC loads in the spring; Sed_sum and Dis_sum are the Sed-OC loads and Dis-OC loads in the summer; Sed_aut and Dis_aut are the SedOC loads and Dis-OC loads in the autumn, respectively. 


\section{Results}

\subsection{Simulation of the NPS OC Pollution Tendency}

The seasonal spatial distributions of NPS OC loads for 2014 are shown in Figure 3. The differences among different seasons are notable in Figure 3. The NPS pollution was the lowest in the winter for both Dis-OC and Sed-OC, while the NPS OC loads increased to their highest in the summer. Specially, the maximum Sed-OC load reached $80.786 \mathrm{~kg} \mathrm{~km}^{-2}$ in the summer, and the maximum Dis-OC load was 12.273. These values were significantly higher than those values in the winter.

Figure 3 demonstrates the evident spatial variation in Sed-OC loads, while the variation among different seasons is relative small. The slightly polluted region occupied more than $60 \%$ region of the entire watershed, and the region severely polluted with Sed-OC was located in the center of the study area for each season. In contrast, the Dis-OC pollution varied more notably in a temporal perspective, in which the southeastern part of the study area was severely polluted in the winter. While the pollution intensity in this region decreased to some extent as the season shifted, the region with the most severe pollution was replaced by the southwesttern corner of the whole watershed.

Table 3 shows the OC loads for each sub-basin. With respect to Sed-OC loads, sub-basins No. 11, No. 12, No. 13 and No. 5 suffered severe NPS pollution intensity for all four seasons. These four sub-basins were loaded with more OC losses than the other sub-basins. In particularly, the region with the most severe pollution was located in sub-basin No. 13, in which the loads reached $4.988 \mathrm{t} \mathrm{km}^{-2}$ in the summer. Regarding the Dis-OC loads, sub-basin No. 3 received more loads than the other sub-basins. However, the situation changed as the season turned into spring and summer. Specially, the most severe pollution appeared in the summer, and sub-basins No. 11 and No. 15 suffered from the highest Dis-OC loads. In addition, the Dis-OC loads also increased rapidly in sub-basin No. 14, which had the highest loads in the autumn. Moreover, sub-basins No. 5, No. 12 and No. 13 suffered from the most severe OC pollution as these two OC load fractions were integrated, and the loads reached $6.06 \mathrm{t} \mathrm{km}^{-2}, 6.10 \mathrm{t} \mathrm{km}^{-2}$ and $7.609 \mathrm{t} \mathrm{km}^{-2}$ for these three sub-basins, respectively.

\subsection{Spatial Pattern of Inflowing River Properties}

To investigate the seasonal variation of inflowing river nutrients, the data of carbon-related indicators within 18 subbasins were analysed for each season (Figure 4).

The DOC concentrations were greater than the POC values, and the maximum value appeared in the summer, in which the DOC concentrations ranged from $16.09 \mathrm{mg} \mathrm{L}^{-1}$ to $53.90 \mathrm{mg} \mathrm{L}^{-1}$, with a mean of $36.44 \mathrm{mg} \mathrm{L}^{-1}$. Furthermore, the variability of the DOC concentrations was the most significant in the summer, with a standard deviation greater than 10.76, compared with standard deviations smaller than 5.0 in the other seasons. The distribution of COD concentrations was similar to that of DOC, and the maximum value also appeared in the summer (ranged from $26.64 \mathrm{mg} \mathrm{L}^{-1}$ to $48.74 \mathrm{mg}$ $\mathrm{L}^{-1}$ ), while the values were slightly lower than those of DOC. In addition, the COD concentrations in the winter were significantly smaller than in the other seasons. In contrast, the POC concentrations were lower without notable variation among different sub-basins. The $a_{\text {CODM }}(443)$ value did not vary notably among different sub-basins in three seasons, including the

Table 3. Statistical Data of NPS P Loads among Different Sub-basins and Different Seasons

\begin{tabular}{lllllll}
\hline \multirow{2}{*}{ No. } & Winter & \multicolumn{5}{c}{ Spring } \\
\cline { 2 - 6 } & $\begin{array}{l}\text { Sed-OC } \\
\left(\mathrm{t} \mathrm{km}^{-2}\right)\end{array}$ & $\begin{array}{l}\text { Dis-OC } \\
\left(\mathrm{t} \mathrm{km}^{-2}\right)\end{array}$ & $\begin{array}{l}\text { Tot-OC } \\
\left(\mathrm{t} \mathrm{km}^{-2}\right)\end{array}$ & $\begin{array}{l}\text { Sed-OC } \\
\left(\mathrm{t} \mathrm{km}^{-2}\right)\end{array}$ & $\begin{array}{l}\text { Dis-OC } \\
\left(\mathrm{t} \mathrm{km}^{-2}\right)\end{array}$ & $\begin{array}{l}\text { Tot-OC } \\
\left(\mathrm{tkm}^{-2}\right)\end{array}$ \\
\hline 1 & 0.696 & 0.886 & 1.582 & 0.595 & 1.839 & 2.434 \\
2 & 0.173 & 0.598 & 0.771 & 0.892 & 1.538 & 2.429 \\
3 & 0.529 & 1.295 & 1.824 & 0.246 & 2.011 & 2.257 \\
4 & 0.313 & 0.680 & 0.993 & 0.719 & 1.488 & 2.207 \\
5 & 1.534 & 0.388 & 1.922 & 1.143 & 1.227 & 2.370 \\
6 & 0.371 & 0.388 & 0.759 & 0.708 & 1.218 & 1.926 \\
7 & 0.277 & 0.354 & 0.631 & 1.087 & 1.234 & 2.321 \\
8 & 0.979 & 0.468 & 1.447 & 0.502 & 0.971 & 1.473 \\
9 & 0.882 & 0.528 & 1.410 & 0.527 & 0.706 & 1.233 \\
10 & 0.447 & 0.619 & 1.067 & 0.340 & 1.300 & 1.640 \\
11 & 0.193 & 0.981 & 1.175 & 1.791 & 2.024 & 3.815 \\
12 & 0.319 & 0.681 & 1.000 & 2.278 & 1.711 & 3.989 \\
13 & 0.650 & 0.676 & 1.326 & 1.678 & 1.353 & 3.031 \\
14 & 0.377 & 0.723 & 1.101 & 0.224 & 1.371 & 1.595 \\
15 & 0.123 & 0.976 & 1.100 & 0.083 & 2.225 & 2.308 \\
16 & 0.033 & 0.638 & 0.671 & 0.367 & 1.531 & 1.898 \\
17 & 0.237 & 0.744 & 0.981 & 0.274 & 1.674 & 1.948 \\
18 & 0.121 & 0.308 & 0.429 & 0.508 & 1.228 & 1.736 \\
\hline
\end{tabular}


Table 3. Statistical Data of NPS P Loads among Different Sub-basins and Different Seasons (Continued)

\begin{tabular}{lllllll}
\hline \multirow{2}{*}{ No. } & Summer & \multicolumn{5}{l}{ Autumn } \\
\cline { 2 - 7 } & $\begin{array}{l}\text { Sed-OC } \\
\left(\mathrm{t} \mathrm{km}^{-2}\right)\end{array}$ & $\begin{array}{l}\text { Dis-OC } \\
\left(\mathrm{t} \mathrm{km}^{-2}\right)\end{array}$ & $\begin{array}{l}\text { Tot-OC } \\
\left(\mathrm{t} \mathrm{km}^{-2}\right)\end{array}$ & $\begin{array}{l}\text { Sed-OC } \\
\left(\mathrm{t} \mathrm{km}^{-2}\right)\end{array}$ & $\begin{array}{l}\text { Dis-OC } \\
\left(\mathrm{t} \mathrm{km}^{-2}\right)\end{array}$ & $\begin{array}{l}\text { Tot-OC } \\
\left(\mathrm{t} \mathrm{km}^{-2}\right)\end{array}$ \\
\hline 1 & 1.452 & 2.839 & 4.291 & 0.549 & 0.662 & 1.211 \\
2 & 4.018 & 2.256 & 6.274 & 1.597 & 1.118 & 2.715 \\
3 & 1.078 & 3.238 & 4.317 & 0.261 & 0.499 & 0.760 \\
4 & 1.757 & 2.757 & 4.514 & 1.098 & 0.810 & 1.908 \\
5 & 4.028 & 2.032 & 6.060 & 1.377 & 1.169 & 2.547 \\
6 & 1.537 & 1.977 & 3.514 & 0.790 & 1.020 & 1.810 \\
7 & 2.550 & 1.880 & 4.430 & 0.943 & 0.916 & 1.859 \\
8 & 1.854 & 2.200 & 4.054 & 0.541 & 1.189 & 1.730 \\
9 & 1.851 & 1.809 & 3.659 & 0.685 & 1.197 & 1.882 \\
10 & 2.637 & 2.374 & 5.011 & 0.957 & 0.861 & 1.818 \\
11 & 2.773 & 3.122 & 5.895 & 1.448 & 0.764 & 2.213 \\
12 & 3.684 & 2.426 & 6.109 & 2.412 & 1.032 & 3.444 \\
13 & 4.988 & 2.621 & 7.609 & 2.427 & 1.340 & 3.768 \\
14 & 1.229 & 2.568 & 3.797 & 0.244 & 1.187 & 1.430 \\
15 & 0.597 & 3.886 & 4.483 & 0.325 & 1.139 & 1.464 \\
16 & 1.066 & 2.364 & 3.430 & 0.323 & 1.092 & 1.416 \\
17 & 1.382 & 3.051 & 4.432 & 0.550 & 1.198 & 1.748 \\
18 & 1.734 & 1.797 & 3.531 & 1.020 & 0.929 & 1.949 \\
\hline
\end{tabular}

winter, spring and autumn, and the values ranged from 2 to 4 for most samples. However, the situation was quite different in the summer, and the $a_{C O D M}(443)$ demonstrated significant difference among the eighteen sub-basins, in which the values ranged from 2.14 to 8.61 , with a mean of 5.86 and standard deviation of 2.01 .

Both the dis-lig and par-lig concentrations exhibited the highest values in the summer and the lowest values in the winter. The dis-lig values in the summer ranged from $2.14 \mathrm{ng}$ $\mathrm{L}^{-1}$ to $7.58 \mathrm{ng} \mathrm{L}^{-1}$, with a mean of $4.87 \mathrm{ng} \mathrm{L}^{-1}$ and standard deviation of 1.50 , while the mean value of dis-lig data in the winter was only $0.55 \mathrm{ng} \mathrm{L}^{-1}$. Moreover, the dis-lig concentrations were significantly greater than the par-lig concentrations in general. The maximum value of par-lig in summer was only $3.09 \mathrm{ng} \mathrm{L}^{-1}$, which was even smaller than the mean value of dis-lig in the same season.

\subsection{The Sensitive Water Indicators to NPS OC Loads}

To comprehensively assess the relationship between NPS OC pollution and inflowing river properties, the correlation coefficients $(r)$ between these parameters within eighteen subbasins and four seasons are shown in Table 4. Results showed that acdom $\left(443 \mathrm{~m}^{-1}\right)$ and lignin were significantly related to NPS OC loads. In particular, the correlation coefficient $(r)$ between acdom $\left(443 \mathrm{~m}^{-1}\right)$ and Dis-OC was as high as 0.729 , and the $\mathrm{r}$ between par-lig and Sed-OC even reached 0.782 .

For a better understanding of the sensitivity of water properties to NPS OC loads, multiple stepwise regressions were performed between selected water properties and the loads of various NPS OC fractions (Table 5). All of the eighteen sub- basins and four seasons were taken into account in the modeling process, the modeling results demonstrated a likeness among three OC load fractions for all sub-basins and seasons, in which the $r^{2}$ values were $0.63,0.68$ and 0.70 for Sed-OC, Dis-OC and Tot-OC, respectively. However, the diversity was notable when regarding the introduced independent variables. Specifically, par-lig became the only introduced independent variable when modeled with Sed-OC. Moreover, both Dis-OC and Tot-OC introduced two independent variables into the modeling process, in which the acdom $\left(443 \mathrm{~m}^{-1}\right)$ and DOC were qualified to link with Dis-OC, whereas the par-lig and dis-lig became the introduced independent variables for TotOC.

\section{Discussion}

\subsection{Contribution of Sed-OC and Dis-OC to NPS OC Loads}

The Taihu Basin has undergone rapid urbanization in recent decades, and the region originally dominated with agricultural land has been gradually replaced by a large area of peri-urban watershed. Moreover, the non-point source pollution was formed from complex sources such as rural-urban and agricultural sediment and runoff. Therefore, for the purpose of more accurate NPS assessment, the SOC losses were categorized into two main fractions, the adsorbed and dissolved fractions.

Our results showed that the Sed-OC loads varied on a spatial scale, and this largely determined the spatial features of Tot-OC (Figure 3). In addition, the peak value of Sed-OC was significantly higher than that of Dis-OC, which was espe- 

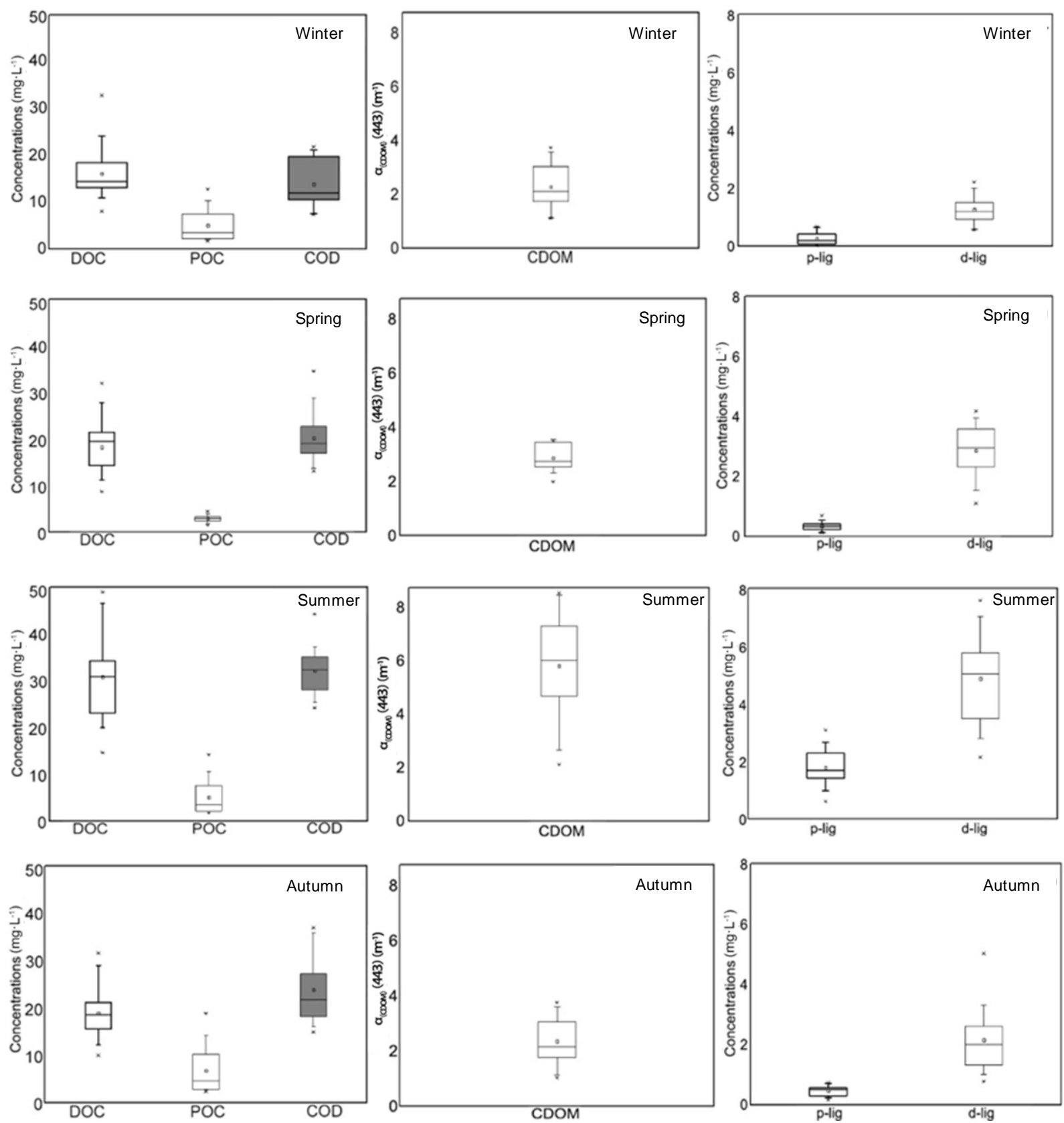

Figure 4. Seasonal statistical data of water indicators within different sub-basins in 2014.

cially reflected in the summer season (Figure 3). The diversity was partly due to the influence of rainfall intensity. It is acknowledged that the rainy season began in the summer and continued until September. From Table 2, it can be found that the rainfall intensity in the summer season, the rainfall intensity on $28 \mathrm{Jul}$ and $9 \mathrm{Aug}, 2014$ exceeded $100 \mathrm{~mm}$. Heavy rainfall always resulted in violent soil erosion in steep areas and was accompanied by higher particulate SOC loads.

A significant different status can be found when the NPS OC pollution loads were clustered according to the eighteen sub-basins (Table 3), which is closely related to the land use
(Clavero et al., 2011; Wu et al., 2012). In this study, the loads of different NPS OC fractions throughout the whole year were clustered according to different land use patterns, and the arable land and orchard land contributed greater Sed-OC loads than the other land use types, as the contribution proportion of arable land was more than 50\% (Figure 5). Great Dis-OC loads were observed on construction land, which contributed $77 \%$ to the total loads. These results supported the findings of previous studies on the relationship between land use and NPS pollution, which have shown that arable land, artificial forestland and orchard land are prone to generate more parti- 
Table 4. Correlation Coefficients (r) between NPS P Loads and Soil Properties

\begin{tabular}{lllllll}
\hline & DOC $\left(\mathrm{mg} \mathrm{L}^{-1}\right)$ & POC $\left(\mathrm{mg} \mathrm{L}^{-1}\right)$ & COD $\left(\mathrm{mg} \mathrm{L}^{-1}\right)$ & $a_{\text {cdom }}\left(443 \mathrm{~m}^{-1}\right)$ & par-lig $\left(\mathrm{mg} \mathrm{L}^{-1}\right)$ & $\operatorname{dis-lig~}\left(\mathrm{mg} \mathrm{L}^{-1}\right)$ \\
\hline Sed-OC & 0.315 & 0.302 & 0.291 & $0.422^{*}$ & $0.782^{* *}$ & $0.605^{* *}$ \\
Dis-OC & $0.609^{* *}$ & 0.107 & $0.421^{*}$ & $0.729^{* *}$ & $0.601^{* *}$ & $0.552^{* *}$ \\
Tot-OC & $0.508^{*}$ & 0.119 & $0.435^{*}$ & $0.644^{* *}$ & $0.720^{* *}$ & $0.672^{* *}$ \\
\hline$*: p<0.05 ; * *: p<0.01$. & & & & &
\end{tabular}

Table 5. Statistical Data of the Multiple Stepwise Regression Results

\begin{tabular}{lllll}
\hline OC load states & No. of introduced independents & Independents & $\mathrm{R}^{2}$ & RMSE \\
\hline Sed-OC & 1 & par-lig & 0.63 & 0.361 \\
Dis-OC & 2 & $a_{\text {cdom }}\left(443 \mathrm{~m}^{-1}\right)$, DOC & 0.68 & 0.605 \\
Tot-OC & 2 & par-lig, dis-lig & 0.70 & 0.248 \\
\hline
\end{tabular}

culate organic matter loss, whereas arable land and impervious surfaces tend to have great dissolved organic matter loss (Ahearn et al., 2005). Furthermore, the results suggested that the role of artificial forestland on NPS loads was not as important as previous studies claimed, probably due to the sporadic forestland region in most of the sub-basins.

\subsection{The Sensitive Inflowing River Properties}

The organic matter in a watershed would be delivered into the corresponding inflowing rivers by NPS pollution and eventually impact on lake aquatic ecosystem (Munafo et al., 2005). Therefore, it is important to establish the relationship between loads of different OC fractions loads and the water properties that are OC-related. Then, the fate of organic matter delivered from watershed soils, as well as the sensitive river indicators, can be deeply discussed.

\section{(i) The role of COD and CDOM}

The COD and CDOM have been acknowledged as reliable markers of NPS pollution (Benner et al., 2004). However, the COD and CDOM demonstrated inconsistent correlations with NPS OC loads. The CDOM was well fitted with Dis-OC loads, with a correlation coefficient of 0.729 , and the correlation coefficient also exceeded 0.644 with respect to the correlation with Tot-OC, suggesting that the Dis-OC loads accounted for a grea-ter proportion in most of the sub-basins. On the contrary, the COD showed an absolutely different status when linked to NPS OC loads. It is necessary to note that several previous studies indicated that the COD was well correlated with urban NPS pollution (Yao et al., 2011). These can partly interpret the better fitting effect between COD and Dis-OC as compared to Sed-OC. However, the study results showed that the COD was not well correlated with NPS OC loads when compared with the other river inflowing properties (Table 4). This may be because the COD concentrations in inflowing rivers are not solely determined by NPS pollution, and the metabolism and release of sediment and aquatic vegetation also play important roles in COD concentrations (Pontier et al., 2004). Actually, the pollution generated by endogenous substance in inflowing rivers was much higher than that in Taihu Lake (Yao et al., 2011). Therefore, the COD concentration in inflowing rivers may not be a suitable maker for

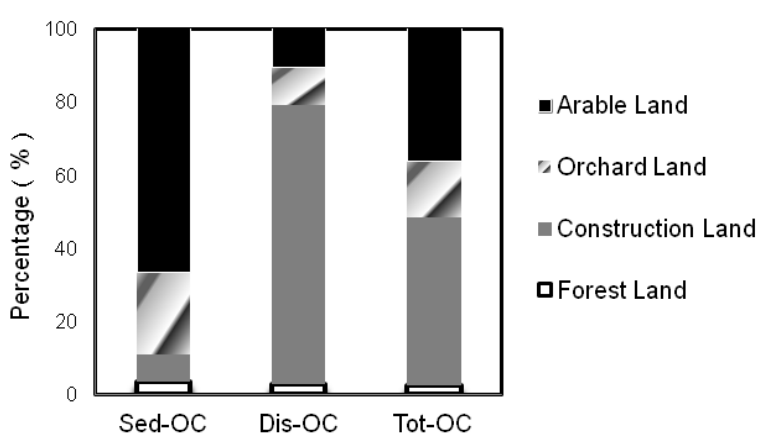

Figure 5. The NPS OC loads for different land use patterns.

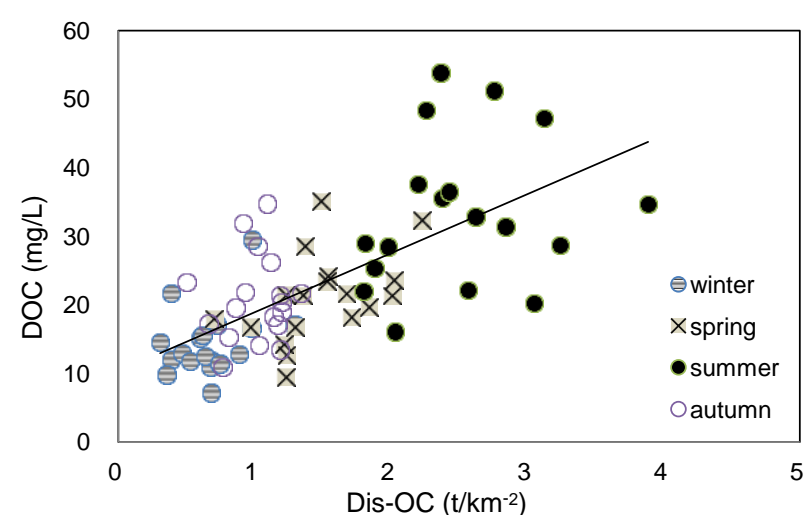

Figure 6. The scatterplots between DOC and Dis-OC loads for different seasons.

NPS OC loads, especially in peri-urban watershed regions.

(ii) The role of DOC and POC

The DOC and POC were acknowledged as the main co-existing fractions of carbon in aquatic ecosystem that correspond to watershed soil particulates and dissolved organic carbon losses directly (Duan et al., 2015). However, the results in our study showed a different situation to some extent. Only the DOC was qualified to introduce into the stepwise regression model targeted to Dis-OC loads, and the $r$ value was only 0.61 , which was not as ideal as some studies suggested (Hernes et al., 2008). To further understand this phenomenon, the scatter graphs between DOC and Dis-OC 


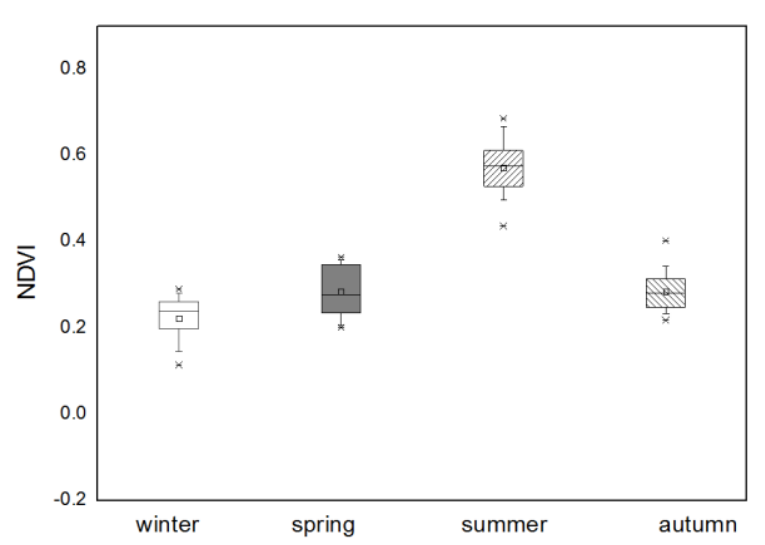

Figure 7. The statistical data of NDVI values for different seasons.

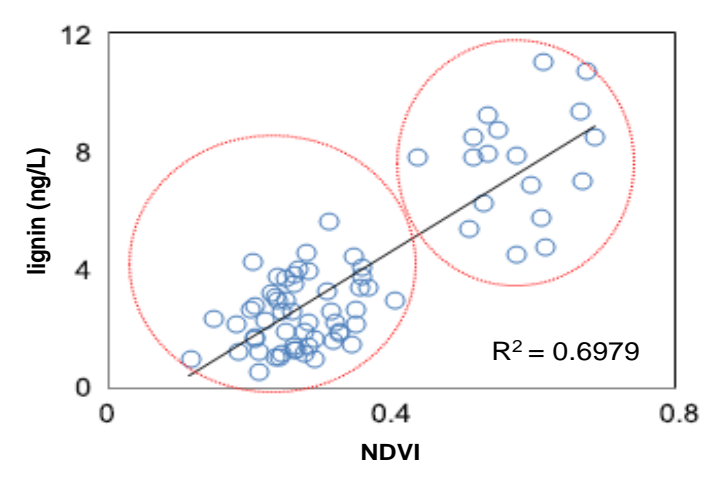

Figure 8. The scatterplots between NDVI and lignin concentrations.

loads for different seasons are shown in Figure 7. The points of the winter, spring and autumn groups were distributed close to the trend line, and the positive correlation between DOC and Dis-OC loads were demonstrated. However, the points of the summer season were irregular distributed and apart from the trend line, suggesting that the watershed Dis-OC loads were not closely related to DOC concentrations in the summer. In other word, regression without data from the summer might result in a stronger relationship. The summer season experienced the most severe NPS OC pollution of the whole year for both particulate and dissolved loss fractions (Table 4 ), and this confirmed the results proposed by Burns et al., (2008). Otherwise, the DOC concentrations also achieved the highest values, while the differences among different subbasins were also more notable than the other seasons regarding the standard deviation and variation indices (Figure 6). In this case, it can be inferred that high Dis-OC loads might not be necessarily followed by greater DOC concentrations in some sub-basins in the summer. Some literature notes that the DOC concentrations are largely affected by climate situations, and DOC can be swiftly broken down by microbes in aquatic environments and transformed into inorganic carbon under high temperature conditions. In addition, more frequent stor$\mathrm{ms}$ in the summer can accelerate DOC decomposition (Dalzell et al., 2005). These results can partly explain the high varia- bility of DOC concentrations and the poor fitting effects with Dis-OC loads in the summer. Regarding the POC concentrations, there was no evident relationship between POC and various OC load fractions (Table 4), possible because the POC was generally the form of carbon that was most readily precipitated as sediment. Furthermore, POC was not the only existing form for watershed NPS Par-OC loss, but the sediment might be the ultimate placement for watershed particulate organic carbon delivery. All of these imply that the POC is not suitable to uncover the watershed NPS Sed-OC loads.

\section{(iii) The role of lignin}

Lignin in lake sediment has been characterized as the important biomarkers of water SOM sources and fate, but the relationship between the lignin and NPS loads in inflowing rivers has rarely studied (Bao et al., 2014). Interestingly, it can be inferred from this study that the lignin may be a suitable and unified inflowing river indicator in relation to NPS pollution.

Lignin is an aromatic polymer and is predominately sourced from surface plants in the watershed. Lignin is rarely generated by the aquatic ecosystem itself (Casas et al., 2014). Therefore, lignin content in waters can be always somehow associated with land vegetation. The NDVI index is an important remote sensing indicator for land surface vegetation coverage, and the NDVI values of different sub-basins distributed in different seasons are shown in Figure 7. It is no surprise that the tendency of the NDVI was similar with the lignin tendency showed in Figure 4. Furthermore, the tendency of NDVI and lignin were also consistent with the NPS OC loads features, and all of them demonstrated significant differences among seasons. These indicators owned the highest values in the summer and the lowest values in the winter. The consistent features showed that the vegetation status was a critical indicator associated with the NPS loads and lignin together. For these cases, the lignin concentrations were correlated with NDVI firstly (Figure 8). The scatter points can be divided into two groups, and the ideal relationship was found when the NDVI value was under 0.4 . The correlation degree became even poorer as the NDVI increased. In addition, it was notable that the scatter points with an NDVI value exceeding 0.4 mostly belonged to the summer (Figure 8). The scatter plots between different NPS OC load fractions and lignin is displayed in Figure 9, which also given consistent results with Figure 8 and is especially reflected in Dis-OC. The relationship between Dis-OC and lignin was poor in the summer, whereas the relationships in the other three seasons were still evident. This phenomenon indicated that the increased NDVI statuses in the winter, spring and autumn were generally accompanied with greater NPS loads, and resulted in more lignin in aquatic ecosystems during the nutrient delivery process. Furthermore, the relationship between the NDVI and watershed NPS pollution in aquatic ecosystems was not simply linear, and the relationship between NPS loads and lignin could also vary among different seasons due to the influence of land surface vegetation, which supported the findings from satellite-derived vegetation indices that are related 

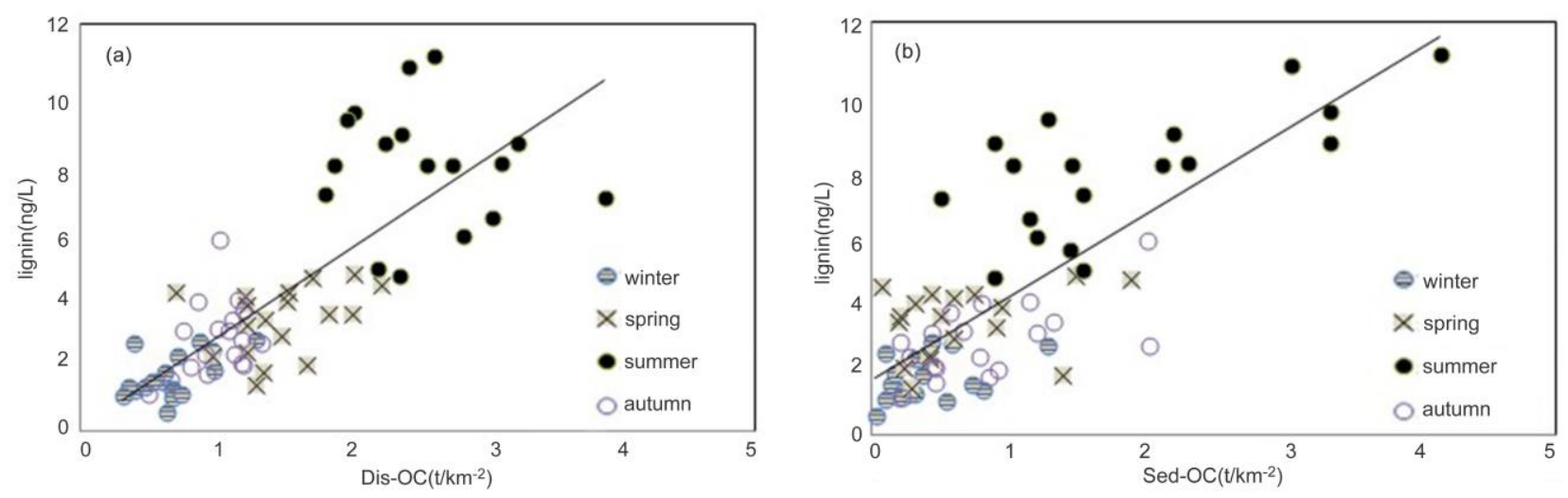

Figure 9. Scatter plots between different NPS OC states loads and lignin concentrations.

to cellulose and lignin in the green-up season (spring) and green senescence (winter) (Ouyang et al., 2009; Woods et al., 2011; Villamuelas et al., 2016).

\subsection{Implication of the Sensitive Inflowing River Proper- ties Detection}

The inflowing rivers are the important bond between watershed and lake. It is necessary to place a particular emphasis on understanding the sensitive river indicators, which can reflect the watershed NPS OC pollution. In our study, six important carbon related indicators were selected, the temporal scale, including four seasons within the whole year, was considered, and both the particulate and dissolved fractions of OC loads were taken into account. Thus, the results further proved that the different OC load fractions and aquatic ecosystem indicators, as well as the seasonal differences, need more detailed consideration for the purpose of better understanding the sensitivity of inflowing carbon-related indicators. A greater temporal series with multiple years may be needed in further studies. Moreover, the selection of a finer watershed scale and a typical inflowing river are also necessary to validate the findings in this study. More importantly, more adequate river indicators including dissolved organic matter (DOM), biochemical oxygen demand (BOD), carbon-nitrogen ratio $(\mathrm{C} / \mathrm{N})$ and a sediment indicator may be needed to be introduced into the research. Furthermore, our study has indicated that river lignin is closely linked to watershed NPS loads. A more detailed consideration of lignin-derived substances in rivers and sediment may become a new focus of studies on the assessment and management of watershed non-point source pollution.

\section{Conclusions}

For the purpose of better understanding which inflowing river indicators are sensitive to watershed NPS OC pollution, the accurate and effective assessment of NPS OC loads is the most important step. The results revealed that, firstly, the DisOC was the main NPS OC load fraction, while the contri- bution of Sed-OC should not be neglected due to a peak value of Sed-OC that was significantly higher than that of Dis-OC in differrent seasons. Secondly, the sensitive water indicators related to NPS OC loads were evaluated. Interestingly, the lignin showed a strong correlation with both Sed-OC and DisOC loads, but nevertheless, its content in inflowing rivers was extremely low. Thirdly, the CDOM and DOC were well linked with Dis-OC fractions, but POC failed to correlate with particulate organic matter loss, possibly because not only the POC but also the sediment was the ultimate fate for watershed particulate organic carbon delivery. Fourthly, more adequate river indicators, including DOM as well as a sediment indicator, are needed in additional research.

The findings of this approach are shown to have value as predictive tools to simplify the representation of watershed NPS loads, and they are also useful for better understanding nutrient delivery from the watershed into the aquatic ecosystem.

Acknowledgments. This work was funded by The National Natural Science Foundation of China (Grant No. 41301227) and the Research Fund of State Key Laboratory of Soil and Sustainable Agriculture, Nanjing Institute of Soil Science, Chinese Academy of Science (Y41 2201427). Data were supported by the Scientific Data Sharing Platform for Lake and Watershed, Nanjing Institute of Geography and Limnology, Chinese Academy of Sciences.

\section{References}

Ahearn, D.S., Sheibley, R.W., Dahlgren, R.A., Anderson, M., Johnson, J., and Tate, K.W. (2005). Land use and land cover influence on water quality in the last free flowing river draining the western Sierra Nevada, California. J. Hydrol., 313(3-4), 234-247. http://dx.doi.org/10.1016/j.jhydrol.2005.02.038

Bao, H.Y., Wu, Y., Zhang, B., Deng, B., and He, Q. (2014). Composition and flux of suspended organic matter in the middle and lower reaches of the Changjiang (Yangtze River) - impact of the Three Gorges Dam and the role of tributaries and channel erosion. Hydrol. Process., 28(3), 1137-1147. http://dx.doi.org/10.1002/hyp. 9651

Basnyat, P., Teeter, L.D., Flynn, K.M., and Lockaby, B.G. (1999). 
Relationships between landscape characteristics and nonpoint source pollution inputs to coastal estuaries. Environ. Manage., 23(4), 539-549. http://dx.doi.org/10.1007/s002679900208

Bechmann, M., Stålnacke, P., Kværnø, S., Eggestad, H.O., and Øygarden, L. (2009). Integrated tool for risk assessment in agricultural management of soil erosion and losses of phosphorus and nitrogen. Sci. Total Environ., 407(2), 749-759. http://dx.doi.org/10. 1016/j.scitotenv.2008.09.016

Benner, R., Benitez-Nelson, B., Kaiser, K., and Amon, R.M.W. (2004). Export of young terrigenous dissolved organic carbon from rivers to the Arctic Ocean. Geophys. Res. Lett., 31(5), 179-211. http://dx.doi.org/10.1029/2003GL019251

Biddanda, B., and Benner, R. (1997). Carbon, nitrogen, and carbohydrate fluxes during the production of particulate and dissolved organic matter by marine phytoplankton. Limnol. Oceanogr., 42(3), 506-518. http://dx.doi.org/10.4319/lo.1997.42.3. 0506

Blair, N.E., and Aller, R.C. (2012). The fate of terrestrial organic carbon in the marine environment. Annu. Rev. Mar. Sci., 4(1), 401423. http://dx.doi.org/10.1146/annurev-marine-120709-142717

Bu, Z.H., Yang, L.Z., Bu, Y.X., and Wu, J.Y. (2002). Soil erodibility $(\mathrm{K})$ value and its application in Taihu lake catchment. Acta Pedol. Sin., 39(3), 296-300 (in Chinese).

Burns, K.A., Brunskill, G., Brinkman, D., and Zagorskis, I. (2008). Organic carbon and nutrient fluxes to the coastal zone from the Sepik River outflow. Cont. Shelf Res., 28(2), 283-301. http:// dx.doi.org/10.1016/j.csr.2007.08.004

Casas, A., Riano, D., Ustin, S.L., Dennison, P., and Salas, J. (2014). Estimation of water-related biochemical and biophysical vegetation properties using multitemporal airborne hyperspectral data and its comparison to MODIS spectral response. Remote Sens. Environ., 148(6), 28-41. http://dx.doi.org/10.1016/j.rse.2014.03.011

Clavero, M., Villero, D., and Brotons, L. (2011). Climate change or land use dynamics: Do we know what climate change indicators indicate? Plos One, 6(4), e18581. http://dx.doi.org/10.1371/jour nal.pone.0018581

Chen, Y., Cheng, S.Y., Liu, L., Guo, X.R., Wang, Z., Qin, C.H., Hao, R.X., Lu, J., and Gao, J.J. (2013). Assessing the effects of land use changes on non-point source pollution reduction for the Three Gorges watershed using the SWAT model. J. Environ. Inf., 22(1), 13-26. http://dx.doi.org/10.3808/jei.201300242

Chen, Z., Li, Y., and Pan, J. (2004). Distributions of colored dissolved organic matter and dissolved organic carbon in the Pearl River Estuary, China. Cont. Shelf Res., 24(16), 1845-1856. http://dx.doi.org/10.1016/j.csr.2004.06.011

Cui, G., Zaheer, I., and Luo, J. (2003). Quantitative evaluation of non-point pollution of Taihu watershed using geographic information system. J. Lake Sci., 15(3), 236-244. http://dx.doi. org/10.18307/2003.0307

Dabral, P.P., Baithuri, N., and Pandey, A. (2008). Soil erosion assessment in a hilly catchment of North Eastern India using USLE, GIS and Remote Sensing. Water Resour. Manage., 22(12), 1783-1798. http://dx.doi.org/10.1007/s11269-008-9253-9

Dalzell, B.J., Filley, T.R., and Harbor, J.M. (2005). Flood pulse influences on terrestrial organic matter export from an agricultural watershed. J. Geophys. Res. (G Biogeosci.), 110(G2), 154-164. http://dx.doi.org/10.1029/2005JG000043

Durigon, V.L., Carvalho, D.F., Antunes, M.A.H., Oliveira, P.T.S., and Fernandes, M.M. (2014). NDVI time series for monitoring RUSLE cover management factor in a tropical watershed. Int. J. Remote Sens., 35(2), 441-453. http://dx.doi.org/10.1080/01431161.2013. 871081

Ferguson, C.A., Carvalho, L., Scott, E.M., Bowman, A.W., and Kirika, A. (2008). Assessing ecological responses to environmental change using statistical models. J. Appl. Ecol., 45(1), 193-203. http://dx.doi.org/10.1111/j.1365-2664.2007.01428.x

Ferro, V. (1997). Further remarks on a distributed approach to sediment delivery. Hydrol. Sci. J., 42(5), 633-647. http://dx.doi. org/10.1080/02626669709492063

Gong, Z.T., Chen, Z.C., and Zhang, G.L. (2003). World reference base for soil resources (WRB): Establishment and development. Soils, 35(4), 271-278 (in Chinese).

Gordon, E.S., and Goñi, M.A. (2003). Sources and distribution of terrigenous organic matter delivered by the Atchafalaya River to sediments in the northern Gulf of Mexico. Geochim. Cosmochim. Acta, 67(13), 2359-2375. http://dx.doi.org/10.1016/S0016-7037(02) 01412-6

He, B. et al. (2012). Analysis of stream water quality and estimation of nutrient load with the aid of Quick Bird remote sensing imagery. Hydrol. Sci. J., 57(5), 850-860. http://dx.doi.org/10.1080/02626 667.2012.683792

Hernes, P.J., Spencer, R.G.M., Dyda, R.Y., Pellerin, B.A., Bachand, P.A.M., and Bergamaschi, B.A. (2008). The role of hydrologic regimes on dissolved organic carbon composition in an agricultural watershed. Geochim. Cosmochim. Acta, 72(21), 52665277. http://dx.doi.org/10.1016/j.gca.2008.07.031

Hood, E., McKnight, D.M., and Williams, M.W.. (2003) . Sources and chemical character of dissolved organic carbon across an alpine/subalpine ecotone, Green Lakes Valley, Colorado Front Range, United States. Water Resour. Res., 39(7). http://dx.doi. org/10.1029/2002WR001738

Jain, M.K., and Kothyari, U.C. (2000). Estimation of soil erosion and sediment yield using GIS. Hydrol. Sci. J., 45(5), 771-786. http://dx.doi.org/10.1080/02626660009492376

Jiang, G., Ma, R., Loiselle, S.A., Duan H. (2012). Optical approaches to examining the dynamics of dissolved organic carbon in optically complex inland waters. Environ. Res. Lett., 7(3), 34014-34019. http://dx.doi.org/10.1088/1748-9326/7/3/034014

Lamb, A.L., Leng, M.J., Mohammed, M.U., and Lamb, H.F. (2004). Holocene climate and vegetation change in the Main Ethiopian Rift Valley, inferred from the composition $(\mathrm{C} / \mathrm{N}$ and $813 \mathrm{C})$ of lacustrine organic matter. Quat. Sci. Rev., 23(7-8), 881-891. http://dx.doi.org/10.1016/j.quascirev.2003.06.010

Laurent, F., and Ruelland, D. (2011). Assessing impacts of alternative land use and agricultural practices on nitrate pollution at the catchment scale. J. Hydrol., 409(1-2), 440-450. http://dx.doi.org/ 10.1016/j.jhydrol.2011.08.041

Li, T.J., Wang, G.Q., Huang, Y.F., and Fu, X.D. (2009). Modeling the process of hillslope soil erosion in the Loess Plateau. J. Environ. Inf., 14(1), 1-10. http://dx.doi.org/10.3808/jei.200900148

Liou, S.M., Lo, S.L., and Wang, S.H. (2004). A generalized water quality index for Taiwan. Environ. Monit. Assess., 96(1), 35-52. http://dx.doi.org/10.1023/B:EMAS.0000031715.83752.a1

McCool, D.K., Brown, G.R., Foster, G.R., Mutchler, C.K., and Meyer, L.D. (1987). Revised slope steepness factor for the universal Soil Loss Equation. Trans. ASAE, 30(5), 1387-1396. http://dx.doi.org/ $10.13031 / 2013.30576$

McDowell, R.W., Sharpley, A.N., and Chalmers A.T. (2002). Land use and flow regime effects on phosphorus chemical dynamics in the fluvial sediment of the Winooski River, Vermont. Ecol. Eng., 18(4), 477-487. http://dx.doi.org/10.1016/S0925-8574(01)00108-2

Munafò, M., Cecchi, G., Baiocco, F., Mancini, L. (2005). River pollution from non-point sources: a new simplified method of assessment. J. Environ. Manage., 77(2), 93-98. http://dx.doi.org/10. 1016/j.jenvman.2005.02.016

Nearing, M.A., Foster, G.R., Lane, L.J., and Finkner, S.C. (1989). A process-based soil erosion model for USDA-Water Erosion Prediction Project technology. Trans. ASAE, 32(5), 1587-1593. 
http://dx.doi.org/10.13031/2013.31195

Neff, J.C., Iii, F.C.S., and Vitousek, P.M. (2003). Breaks in the cycle: dissolved organic nitrogen in terrestrial ecosystems. Front. Ecol. Environ., 1(4), 205-211. http://dx.doi.org/10.1890/1540-9295(2003) 001[0205:BITCDO]2.0.CO;2

Ning, S.K., Chang, N.B., Jeng, K.Y., and Tseng, Y.H.(2006) . Soil erosion and non-point source pollution impacts assessment with the aid of multi-temporal remote sensing images. J. Environ. Manage., 79(1), 88-101. http://dx.doi.org/10.1016/j.jenvman.2005. 05.019

Onyando, J.O., Kisoyan, P., and Chemelil, M.C. (2005). Estimation of potential soil erosion for river perkerra Catchment in Kenya. Water Resou. Manage., 19(2), 133-143. http://dx.doi.org/10.1007/ s11269-005-2706-5

Ouyang, W., Skidmore, A.K., Hao, F., and Wang, T. (2010). Soil erosion dynamics response to landscape pattern. Sci. Total Environ., 408(6), 1358-1366. http://dx.doi.org/10.1016/j.scitotenv. 2009.10.062

Ouyang, W., Wang, X., Hao, F., and Srinivasan, R. (2009). Tempora-spatial dynamics of vegetation variation on non-point source nutrient pollution. Ecol. Modell., 220(20), 2702-2713. http://dx.doi.org/10.1016/j.ecolmodel.2009.06.039

Pontier, H., Williams, J.B., and May, E. (2004). Progressive changes in water and sediment quality in a wetland system for control of highway runoff. Sci. Total Environ., 319(1-3), 215-224. http://dx. doi.org/10.1016/S0048-9697(03)00410-8

Santhi, C., Arnold, J.G., Williams, J.R., Dugas, W.A., Srinivasan, R., and Hauck, L.M. (2001). Validation of the SWAT model on a large river basin with point and nonpoint sources. J. Am. Water Resour. Assoc., 37(5), 1169-1188. http://dx.doi.org/10.1111/j.1752-1688.20 01.tb03630.x

Shi, Q., Deng, X., Wu, F., Zhan, J., and Xu, L. (2012). Best management practices for agricultural non-point source pollution control using PLOAD in Wuliangsuhai watershed. J. Food Agric. Environ., 10(2), 1389-1393.

Smith, P., and Maidment, D. (1995). Hydrologic Data Development System, CRWR Online Report 95-1, Austin, Center for Research in Water Resource, The University of Texas at Austin.

Ŝtambuk-Gilijanović, N. (2003). Comparison of dalmatian water evaluation indices. Water Environ. Rese., 75(5), 388-405. http://dx.doi.org/10.2175/106143003X141196

Teisserenc, R., Locutte, M., Houel, S., and Carreau, J. (2010). Integrated transfers of terrigenous organic matter to lakes at their watershed level: A combined biomarker and GIS analysis. Geochim. Cosmochim. Acta, 74(22), 6375-6386. http://dx.doi.org/ 10.1016/j.gca.2010.08.029

USEPA. (2003). National Management Measures for the Control of Non-point Pollution from Agriculture, Washington, D.C., United States Environmental Protection Agency Office of Water.

Villamuelas, M. et al. (2015). The Enhanced Vegetation Index (EVI) as a proxy for diet quality and composition in a mountain ungulate.
Ecol. Indicators, 61(Part 2), 658-666. http://dx.doi.org/10.1016/j. ecolind.2015.10.017

Wang, X., Wang, Q., Liang, T., Zheng, D., Wei, X., and Wu, C. (2012). A method coupled with remote sensing data to evaluate non-point source pollution in the Xin'anjiang catchment of China. Sci. Total Environ., 430, 132-143. http://dx.doi.org/10.1016/j.scito tenv.2012.04.052

Wischmeier, W.H., and Smith, D.D. (1978). Predicting rainfall erosion losses - a guide to conservation planning, Agricultural Handbook, Department of Agriculture-Agricultural Research Service, Washington, DC.

Woods, G.C., Simpson, M.J., Pautler, B.G., Lamoureux, S.F., Lafrenière, M.J., and Simpson, A.J. (2011). Evidence for the enhanced lability of dissolved organic matter following permafrost slope disturbance in the Canadian High Arctic. Geochim. Cosmochim. Acta, 75(22), 7226-7241. http://dx.doi.org/10.1016/ j.gca.2011.08.013

Wu, L., Long, T.Y., Liu, X., and Guo, J.S. (2012). Impacts of climate and land-use changes on the migration of non-point source nitrogen and phosphorus during rainfall-runoff in the Jialing River Watershed, China. J. Hydrol., 475(12), 26-41. http://dx.doi.org/10. 1016/j.jhydrol.2012.08.022

Wu. Y., and Chen, J. (2013). Estimating irrigation water demand using an improved method and optimizing reservoir operation for water supply and hydropower generation: a case study of the Xinfengjiang reservoir in southern China. Agric. Water Manage., 116, 110-121. http://dx.doi.org/10.1016/j.agwat.2012.10.016

Xu, L., Xu, X., and Meng, X. (2012). Risk assessment of soil erosion in different rainfall scenarios by RUSLE model coupled with Information Diffusion Model: A case study of Bohai Rim, China. Catena, 100, 74-82. http://dx.doi.org/10.1016/j.catena.2012.08.012

Yamashita, Y., and Tanoue, E. (1988). Production of bio-refractory fluorescent dissolved organic matter in the ocean interior. Nat. Geosci., 1, 579-582. http://dx.doi.org/10.1038/ngeo279

Yang, M., Li, X., Hu, Y., and He, Y. (2012). Assessing effects of landscape pattern on sediment yield using sediment delivery distributed model and a landscape indicator. Ecol. Indicators, 22, 38-52. http://dx.doi.org/10.1016/j.ecolind.2011.08.023

Yao, X., Zhang, Y., Zhu, G., Qin, B, Feng, L., Cai, L and Gao,G. (2011). Resolving the variability of CDOM fluorescence to differentiate the sources and fate of DOM in Lake Taihu and its tributaries. Chempsphere, 82(2), 145-155. http://dx.doi.org/10. 1016/j.chemosphere.2010.10.049

Zhang, Y., Dijk M.A.V., Liu, M., Zhu, G., and Qin, B.Q. (2009). The contribution of phytoplankton degradation to chromophoric dissolved organic matter (CDOM) in eutrophic shallow lakes: field and experimental evidence. Water Research. 43(18), 4685-4697. http://dx.doi.org/10.1016/j.watres.2009.07.024 